\title{
Quantitative detection of Aeromonas salmonicida in fish tissue by real-time PCR using self-quenched, fluorogenic primers
}

\author{
José Luis Balcázar, Daniel Vendrell, Ignacio de Blas, Imanol Ruiz-Zarzuela, \\ Olivia Gironés and José Luis Múzquiz
}

Correspondence

José Luis Balcázar

balcazar@unizar.es

Received 27 March 2006

Accepted 6 November 2006

\author{
Laboratory of Fish Pathology, Faculty of Veterinary Sciences, University of Zaragoza, 50013 \\ Zaragoza, Spain
}

\begin{abstract}
In this study a real-time PCR assay using self-quenched primers labelled with a single fluorophore for the detection of Aeromonas salmonicida was developed. Probe specificity was confirmed by amplification of $16 \mathrm{~A}$. salmonicida strain templates and by the lack of a PCR product with 26 non- $A$. salmonicida strains. With a pure culture of $A$. salmonicida, the assay was linear over a range of $0.5 \mathrm{pg}$ to $50 \mathrm{ng}$ and was able to detect 16 c.f.u. per reaction. A similar sensitivity was observed in DNA extracted from a mixture of $A$. salmonicida and fish tissue. Results using artificially inoculated tissues and diseased fish from outbreaks indicated that the assay can provide sensitive species-specific detection and quantification of $A$. salmonicida in fish tissue.
\end{abstract}

\section{INTRODUCTION}

Aeromonas salmonicida is the aetiological agent of furunculosis, a disease that affects many species of fish and is a significant cause of economic losses in the aquaculture of trout and salmon (McCarthy \& Roberts, 1980; O'Brien et al., 1994). The disease is characterized by the presence of general septicaemia, lack of appetite, lethargy and haemorrhagic and necrotic lesions in gills, gut and muscle (Hiney \& Olivier, 1999). This bacterium has also been associated with ulcer disease in carp and marine flatfish and erythrodermatitis in carp (Austin \& Austin, 1999).

Methods currently used to identify A. salmonicida within infected fish can be time-consuming, labour-intensive and hard to implement because of difficulties in distinguishing the bacterium from other bacterial species given the wide variety of existing biochemical profiles, the absence of an efficient selective medium and the poor plating efficiency of the bacterium in mixed cultures. For this reason, attention has focused on the application of different serological techniques (Adams \& Thompson, 1990; Gilroy \& Smith, 2003), and DNA sequence-based methods employing PCR have been developed (Gustafson et al., 1992; Hiney et al., 1992; Miyata et al., 1996).

Real-time PCR technology may be able to provide an innovative method of detecting and enumerating several

Abbreviations: $C_{t}$, cycle threshold; FAM, 6-carboxyfluorescein; LUX, Light Upon eXtension.

The GenBank/EMBL/DDBJ accession numbers for the 16S rRNA gene sequences of the $A$. salmonicida strains determined in this study are AM296501-AM296510. organisms in different environments (Sharkey et al., 2004). With this method, PCR product accumulation is continuously monitored during cycle progression by means of fluorescent detection. In addition, this technique is characterized by a large dynamic range of quantification, sensitivity and throughput capacity and requires no postamplification manipulation, thus avoiding possible carryover contamination.

A fluorescence-based PCR technique that uses a fluorogenic primer labelled with a single fluorophore was recently developed as a cost-effective alternative to other fluorescence-based PCR techniques (Nazarenko et al., 2002a, b). Light Upon eXtension (LUX) primers (Invitrogen) are designed with the fluorophore attached near the $3^{\prime}$ end and a short complementary sequence at the $5^{\prime}$ end that creates a hairpin structure. This structure effectively quenches the fluorophore so that a separate quenching moiety is not required. When the primer is incorporated into a doublestranded PCR product and extended by DNA polymerase, the fluorophore is dequenched, resulting in a significant increase in fluorescent signal (Lowe et al., 2003).

The most frequent target of species-specific A. salmonicida DNA probes and PCR assays is a $6.4 \mathrm{~kb}$ cryptic plasmid known to occur in $90 \%$ of $A$. salmonicida subsp. salmonicida (Hiney et al., 1992; Sørum et al., 1993; O’Brien et al., 1994; Mooney et al., 1995; Byers et al., 2002). This locus is also found in all A. salmonicida subsp. achromogenes strains tested and some A. salmonicida subsp. masoucida strains. No reaction has been found with over 60 related aeromonads and aquatic bacteria tested to date (Mooney et al., 1995). 
The present study employed this locus to develop a quantitative real-time PCR assay using fluorogenic primers. Assay sensitivity and specificity were examined in pure or mixed cultures, and enumeration of A. salmonicida by real-time PCR in tissue samples from rainbow trout (Oncorhynchus mykiss) was carried out.

\section{METHODS}

Bacterial strains and culture conditions. A total of 40 bacterial strains comprising A. salmonicida $(n=16)$ and non- $A$. salmonicida strains $(n=26)$ was employed to test the specificity of the PCR assay (Table 1). Strains were obtained from the following sources: ATCC (American Type Culture Collection, Manassas, VA, USA), NCIMB (National Collections of Industrial and Marine Bacteria, Aberdeen, UK) and LMG (Laboratory for Microbiology, Ghent University, Belgium), as indicated in Table 1; strains CLFP 501-505, isolated from rainbow trout during a furunculosis outbreak at fish farms, from the Autonomous Community of Aragon, Spain; strains 2320, 793 and 4814 from Dr D. Colquhoun (Department for Fish Health, National Veterinary Institute, Oslo, Norway); strains 265/87, MT-004, F-661-2/89, Fin 3, 870626-1/1C, S-228/91, S-123-91-1, Vib 293, Vib 305, Vib 281 and M 147/92 from Dr B. K. Gudmundsdóttir (Institute for Experimental Pathology, University of Iceland, Reykjavík, Iceland); strains 146 and 147 from Dr José Guijarro (Department of Functional Biology, University of Oviedo, Spain); strains CECT 4342, CECT 4224, CECT 4245, CECT 4227, CECT 4257, CECT 4199, CECT 5761 and CECT 4237 from Dr María José Figueras (Biology and Microbiology Research Unit, Rovira and Virgili University, Spain); and strains Rs 146 and Rs 147 from Dr Eva Jansson (Department of Wild Life, Fish and Environment, National Veterinary Institute, Sweden). All strains were grown in brain heart infusion broth (Scharlau Chemie) overnight at $22^{\circ} \mathrm{C}$, with the exception of Flavobacterium psychrophilum, which was grown in Anackel-Ordal broth (0.5\% tryptone, $0.05 \%$ yeast extract, $0.02 \%$ sodium acetate, $0.02 \%$ beef extract, adjusted to $\mathrm{pH} 7.4$ ) for 2 days at $15{ }^{\circ} \mathrm{C}$ with agitation, and Renibacterium salmoninarun, which was grown in modified KDM2 broth ( $1 \%$ bactopeptone, $0.05 \%$ yeast extract, $0.05 \%$ L-cysteine, adjusted to $\mathrm{pH} 6.5$ ) for 6 days at $15^{\circ} \mathrm{C}$ with agitation.

165 rRNA gene sequencing. In order to ensure that strains were A. salmonicida, the $16 \mathrm{~S}$ rRNA gene sequence was PCR amplified in a Perkin-Elmer GeneAmp PCR System 2400 thermocycler, as described by Suzuki et al. (1996). The PCR products were sequenced directly using the prokaryotic $16 \mathrm{~S}$ rRNA gene universal primers $27 \mathrm{~F}$ (5'-AGAGTTTGATCCTGGCTCAG-3') and 1492R (5'-GGTTACCTTGTTACGACTT- $3^{\prime}$ ) on a MegaBACE 500 sequencer following the manufacturer's protocols (Amersham Biosciences). Sequences were corrected manually and aligned with 16S rRNA gene sequences obtained from the GenBank database using the BLAST algorithm (Altschul et al., 1990). Subsequent multiple alignments were carried out using CLUSTAL W (Thompson et al., 1994).

DNA extractions. Bacterial cultures $(1.0 \mathrm{ml})$ were homogenized in $200 \mu \mathrm{TE}$ buffer [10 mM Tris/HCl (pH 8.0), 1 mM EDTA], centrifuged at $12000 \mathrm{~g}$ for $1 \mathrm{~min}$ and pellets were extracted using InstaGene Matrix (Bio-Rad) following the manufacturer's instructions. DNA yield and purity were determined spectrophotometrically by measuring $A_{260}: A_{280}$ ratios (Gene Quant pro RNA-DNA calculator; Amersham Pharmacia Biotech). Concentrated DNA was stored at $-20{ }^{\circ} \mathrm{C}$.

Fluorogenic real-time PCR. Oligonucleotide sequences were derived from a specific DNA probe for A. salmonicida (GenBank accession no. X64214). The probe is specific for a region of the
Table 1. Bacterial strains detected by real-time PCR

\begin{tabular}{|c|c|}
\hline Isolate & Detection \\
\hline A. salmonicida subsp. salmonicida CLFP 501 & + \\
\hline A. salmonicida subsp. salmonicida CLFP 502 & + \\
\hline A. salmonicida subsp. salmonicida CLFP 503 & + \\
\hline A. salmonicida subsp. salmonicida CLFP 504 & + \\
\hline A. salmonicida subsp. salmonicida CLFP 505 & + \\
\hline A. salmonicida subsp. salmonicida 793 & + \\
\hline A. salmonicida subsp. salmonicida MT-004 & + \\
\hline A. salmonicida subsp. salmonicida NCIMB 1102 & + \\
\hline A. salmonicida subsp. salmonicida 4814 & + \\
\hline A. salmonicida subsp. achromogenes 2320 & + \\
\hline A. salmonicida subsp. achromogenes NCIMB 1110 & + \\
\hline A. salmonicida subsp. achromogenes $265 / 87$ & + \\
\hline A. salmonicida subsp. achromogenes F-661-2/89 & + \\
\hline A. salmonicida subsp. achromogenes $870626-1 / 1 \mathrm{C}$ & + \\
\hline A. salmonicida subsp. masoucida Fin 3 & + \\
\hline A. salmonicida subsp. masoucida NCIMB 2020 & + \\
\hline Aeromonas encheleia CECT 4342 & - \\
\hline Aeromonas eucrenophila CECT 4224 & - \\
\hline Aeromonas sobria CECT 4245 & - \\
\hline Aeromonas bestiarum CECT 4227 & - \\
\hline Aeromonas veronii CECT 4257 & - \\
\hline Aeromonas allosaccharophila CECT 4199 & - \\
\hline Aeromonas culicicola CECT 5761 & - \\
\hline Aeromonas media CECT 4237 & - \\
\hline Aeromonas hydrophila S-123-91-1 & - \\
\hline Aeromonas hydrophila S-228/91 & - \\
\hline Vibrio tubiashii LMG 10936 & - \\
\hline Vibrio fluvialis NCIMB 2249 & - \\
\hline Vibrio splendidus NCIMB 2251 & - \\
\hline Vibrio furnissii Vib 293 & - \\
\hline Vibrio pelagius Vib 305 & - \\
\hline Vibrio aestuarianus Vib 281 & - \\
\hline Vibrio anguillarum ATCC 19264 & - \\
\hline Moritella viscosa M 147/92 & - \\
\hline Photobacterium phosphoreum NCIMB 844 & - \\
\hline Yersinia ruckeri ATCC 29473 & - \\
\hline Y. ruckeri 146 & - \\
\hline Y. ruckeri 147 & - \\
\hline Flavobacterium psychrophilum NCIMB 1947 & - \\
\hline F. psychrophilum NCIMB 1826 & - \\
\hline Renibacterium salmoninarum Rs 146 & - \\
\hline R. salmoninarum Rs 147 & - \\
\hline
\end{tabular}

+, Fluorescent signal detected after 15-40 cycles; -, no fluorescent signal detected after 40 cycles.

DNA fragment that has been used previously as a species-specific genetic probe (Hiney et al., 1992). LUX designer software (www. invitrogen.com/lux) was used to design the LUX fluorogenic primers [5'-CGGAACGTAATCTGAATTGTTCTTTTC(FAM)G-3'] and (5'ATTGCTTATCGAGGCAGCCAAC-3').

For this assay, each $50 \mu \mathrm{l}$ PCR contained $25 \mu$ Platinum Quantitative PCR SuperMix-UDG (uracil DNA glycosylase) [60 U Platinum Taq DNA polymerase $\mathrm{ml}^{-1}, 40 \mathrm{mM}$ Tris/ $\mathrm{HCl}(\mathrm{pH} \mathrm{8.4}), 100 \mathrm{mM} \mathrm{KCl}$, 
$6 \mathrm{mM} \mathrm{MgCl}_{2}, 400 \mu \mathrm{M}$ each dGTP, dATP and dCTP, $800 \mu \mathrm{M}$ dUTP, $40 \mathrm{U}$ UDG $\mathrm{ml}^{-1}$ and stabilizers], FAM-labelled LUX primer and corresponding unlabelled primer ( $200 \mathrm{nM}$ each final concentration), $1 \mu \mathrm{l}$ ROX reference dye (Invitrogen) and $10 \mu \mathrm{l}$ template. An ABI PRISM 7000 was programmed as follows: $50{ }^{\circ} \mathrm{C}$ for $2 \mathrm{~min}$ and denaturation at $95^{\circ} \mathrm{C}$ for $2 \mathrm{~min}$, followed by 40 cycles of $95^{\circ} \mathrm{C}$ for $15 \mathrm{~s}$, $55^{\circ} \mathrm{C}$ for $30 \mathrm{~s}$ and $72^{\circ} \mathrm{C}$ for $30 \mathrm{~s}$. Data were analysed using ABI PRISM 7000 sequence detection software, version 1.2.3 (Applied Biosystems). The cycle threshold $\left(\mathrm{C}_{\mathrm{t}}\right)$ was calculated as the cycle number at which the reaction became exponential. The $\mathrm{C}_{t}$ of each sample was then compared with a standard curve and the result was expressed as absolute amounts of genomic DNA. Standard curves for quantification were plotted from triplicate samples by using $C_{t}$ values of tenfold dilutions of template extracted from $8 \times 10^{6}$ c.f.u. A. salmonicida NCIMB $1102 \mathrm{ml}^{-1}$. To confirm the results of the real-time PCR, $10 \mu \mathrm{l}$ aliquots of PCR products were analysed by electrophoresis on ethidium bromide-stained $2 \%$ agarose gels (Bio-Rad).

Sensitivity and specificity of the real-time PCR assay. The specificity of the real-time PCR was determined by comparing PCR products derived from $A$. salmonicida $(n=16)$ and non- $A$. salmonicida strain $(n=26)$ DNA templates. For sensitivity assays, DNA was extracted from pure cultures of A. salmonicida NCIMB 1102 $\left(8 \times 10^{6}\right.$ c.f.u. $\left.\mathrm{ml}^{-1}\right)$ to generate a standard curve used for enumeration of unknown samples.

Detection of seed $\boldsymbol{A}$. salmonicida in fish tissue homogenate. Tissue samples (250 mg kidney, liver, spleen or intestine) from rainbow trout were homogenized in a $1 \mathrm{ml}$ suspension of early stationary phase A. salmonicida NCIMB 1102 cells diluted in deionized water to a final concentration of 32,320 and 3200 c.f.u. (g tissue $)^{-1}$. Homogenates were centrifuged at $12000 \mathrm{~g}$ for $1 \mathrm{~min}$ and DNA was extracted using InstaGene matrix following the manufacturer's instructions. Enumeration of A. salmonicida by real-time PCR was compared with plate count values. Statistical analysis was based on Student's $t$-test using paired and equal variance of $\log$ c.f.u. $\mathrm{g}^{-1}$. All statistics were performed using SPSS for Windows version 11.5 (SPSS).

Detection of $\boldsymbol{A}$. salmonicida in naturally infected fish. Tissue samples $(250 \mathrm{mg})$ of diseased fish associated with outbreaks on different fish farms were also tested. Samples were homogenized in $1 \mathrm{ml}$ deionized water. Homogenates were centrifuged at $12000 \mathrm{~g}$ for $1 \mathrm{~min}$ and DNA was extracted as described above.

\section{RESULTS AND DISCUSSION}

The fluorogenic primer method has several advantages over other methods, including ease of design and synthesis of the primers. The design of these primers is based on studies that demonstrate the effects of the primary and secondary structure of oligonucleotides on the emission properties of a conjugated fluorophore (Nazarenko et al., 2002b). The primers are chemically synthesized oligonucleotides (22-29 nt) with a fluorophore attached to the C5 position of thymidine, which increases its fluorescence when incorporated into a double-stranded PCR product. This phenomenon results from (i) having the fluorophore close to the $3^{\prime}$ end of an oligonucleotide with $\mathrm{G}$ or $\mathrm{C}$ at the $3^{\prime}$ end, (ii) the existence of a $\mathrm{G}$ within a few bases of the label and (iii) the ability of the oligonucleotide to form a blunt-ended hairpin at temperatures close to the annealing temperature of the primer (Nazarenko et al., 2002a).

\section{Primer design}

LUX fluorogenic primers were designed from a specific DNA probe for A. salmonicida (Hiney et al., 1992), as 16S rRNA gene sequence analysis did not provide sufficient information for the delineation and identification of most species of the genera Aeromonas. It has been reported that A. salmonicida and Aeromonas bestiarum type strains differ by only two nucleotides, at positions 1011 and 1018 (Martínez-Murcia et al., 2005).

A computer search using tBLASTX (Altschul et al., 1997) for the matching sequences in GenBank including updates against the DNA probe for A. salmonicida (GenBank accession no. X64214) as a query sequence revealed more than $97 \%$ similarity with plasmids from A. salmonicida subspecies listed in the NCBI genome database. The tBLASTX search also found that the DNA probe for A. salmonicida shared $47 \%$ identity with the YopP gene from Yersinia enterocolitica (GenBank accession no. AF023202), which induces apoptosis in mouse macrophages (Mills et al., 1997). Because of the similarity between the DNA probe for A. salmonicida and the YopP gene from Y. enterocolitica, the extreme $5^{\prime}$-end region of the sequence was targeted, as this is where the most sequence variation occurs between the two.

\section{Specificity of detection}

To improve the diagnosis capabilities for this bacterial pathogen, a real-time PCR assay was developed. Species specificity was confirmed by positive amplification of all 16 isolates of A. salmonicida and lack of a product from ten other strains of Aeromonas species (Aeromonas encheleia, Aeromonas eucrenophila, Aeromonas sobria, A. bestiarum, Aeromonas veronii, Aeromonas allosaccharophila, Aeromonas culicicola, Aeromonas media and Aeromonas hydrophila) and 16 strains of common bacterial fish pathogens (Flavobacterium psychrophilum, Moritella viscosa, Photobacterium phosphoreum, Renibacterium salmoninarum, Vibrio tubiashii, Vibrio fluvialis, Vibrio splendidus, Vibrio furnissii, Vibrio pelagius, Vibrio aestuarianus, Vibrio anguillarum and Yersinia ruckeri) (Table 1). The size of the amplified PCR product (131 bp) was verified by gel electrophoresis (not shown).

Byers et al. (2002) showed that primers PAAS1 and PAAS2, previously designed from the same sequence used in the present study (Hiney et al., 1992), did not produce any falsepositive reactions with 27 non-target bacterial DNA extracts and these primers were considered to be specific for $A$. salmonicida. However, the PAAS primer set correctly identified only $285 / 308$ isolates as A. salmonicida and was therefore determined to have an in vitro sensitivity of $93 \%$. The failure of the PAAS primer set to identify $100 \%$ of the $A$. salmonicida isolates appeared to be related to the primer target site, which had previously been shown to occur on a $6.4 \mathrm{~kb}$ cryptic plasmid (Sørum et al., 1993) and to be present in approximately $90 \%$ of $A$. salmonicida isolates (Mooney et al., 1995). It is therefore reasonable to speculate that the 


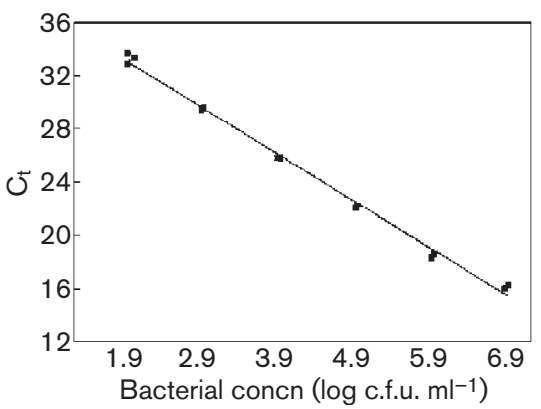

Fig. 1. Standard curve for quantification, plotted from triplicate samples using $C_{t}$ values of tenfold dilutions of template extracted from $8 \times 10^{6}$ c.f.u. A. salmonicida NCIMB $1102 \mathrm{ml}^{-1}$.

specificity of the reaction could be related to the virulence of the strains, as all A. salmonicida strains used in the present study were isolated from disease outbreaks in O. mykiss, Salmo salar, Salvelinus alpinus and Zoarces viviparus. In addition, the probe sequence homology with the YopP gene from $Y$. enterocolitica could confirm this hypothesis.

\section{Sensitivity of detection}

The detection sensitivity of the real-time PCR assay was determined by testing triplicate sets of genomic DNA prepared from serial dilutions $\left(8 \times 10^{1}\right.$ to $8 \times 10^{6}$ c.f.u. $\mathrm{ml}^{-1}$ ) of A. salmonicida NCIMB 1102. The results were reported as $C_{t}$ values versus log starting quantities of DNA. Positive signals were found in all dilutions except those where the DNA concentration was below $5 \times 10^{-4} \mathrm{ng} \mu \mathrm{l}^{-1}$ $\left(80\right.$ c.f.u. $\mathrm{ml}^{-1}$ ). The $\mathrm{C}_{\mathrm{t}}$ values were also plotted against c.f.u. $\mathrm{ml}^{-1}\left(8 \times 10^{1}\right.$ to $8 \times 10^{6}$ c.f.u. $\left.\mathrm{ml}^{-1}\right)$ in tenfold serial dilutions of the A. salmonicida NCIMB 1102 culture used for extracting genomic DNA. Based on this approach, a correlation was observed between $C_{t}$ and c.f.u. $\mathrm{ml}^{-1}$ of the starting quantity of $A$. salmonicida NCIMB 1102 DNA (Fig. 1).

The standard curve demonstrated a $\mathrm{C}_{\mathrm{t}}$ value of around 15 for $50 \mathrm{ng}$ DNA ( $\log 6.9$ c.f.u. $\mathrm{ml}^{-1}$ ) with a slope close to -3.53 , indicating good sensitivity. The high coefficient of determination $\left(R^{2}=0.99\right)$ obtained in the assay showed a strong correlation between template DNA concentrations ranging from $0.5 \mathrm{pg}$ to $50 \mathrm{ng}$ and the $\Delta R_{n}$ signal and indicated that the assay is useful for quantitative measurements of $A$. salmonicida.

The real-time PCR detection limit for A. salmonicida DNA derived from pure culture was $0.5 \mathrm{pg}$ PCR mixture $\mu \mathrm{l}^{-1}$, or the equivalent of 80 c.f.u. ( $\mathrm{ml}$ culture) $)^{-1}$, which would extrapolate to 16 c.f.u. per PCR assay, assuming $100 \%$ extraction efficiency.

\section{Detection of $\boldsymbol{A}$. salmonicida in fish tissues}

The $\mathrm{C}_{\mathrm{t}}$ values obtained from the analysis of tissue samples were extrapolated to the corresponding previously calculated standard curve. The presence of fish tissue did not affect real-time PCR detection of A. salmonicida NCIMB 1102 , and the results of plate counts yielded a good correlation $(r=0.85)$ between the two assays (Table 2). On the other hand, amplification products were not detected when tissues were inoculated independently with 32 c.f.u. (g culture $)^{-1}$.

In order to check the potential application of this PCR in natural infections, some samples from natural outbreaks were processed (Table 3 ). These preliminary results showed

Table 2. Quantification of $A$. salmonicida from inoculated tissues

\begin{tabular}{|lccc|}
\hline Sample & $\begin{array}{c}\text { Inoculum } \\
\left(\mathbf{l o g} \text { c.f.u. } \mathbf{g}^{\mathbf{- 1}}\right)\end{array}$ & $\begin{array}{c}\text { Plate count } \\
\left(\mathbf{l o g} \text { c.f.u. } \mathbf{g}^{-\mathbf{1}} \pm \mathbf{S D}\right)\end{array}$ & $\begin{array}{c}\text { Real-time PCR } \dagger \\
{\left[\mathbf{l o g} \text { c.f.u. } \mathbf{g}^{-\mathbf{1}} \pm \text { SD }\left(\mathbf{C}_{\mathbf{t}} \pm \text { SD }\right)\right.}\end{array}$ \\
\hline Kidney & 3.5 & $3.64 \pm 0.14$ & $3.53 \pm 0.06(29.1 \pm 0.56)$ \\
Kidney & 2.5 & $2.57 \pm 0.12$ & $2.66 \pm 0.04(32.6 \pm 0.42)$ \\
Spleen & 3.5 & $3.56 \pm 0.06$ & $3.30 \pm 0.07(30.1 \pm 0.78)$ \\
Spleen & 2.5 & $2.48 \pm 0.12$ & $2.32 \pm 0.11(34.1 \pm 0.77)$ \\
Liver & 3.5 & $3.55 \pm 0.08$ & $3.26 \pm 0.08(30.3 \pm 0.08)$ \\
Liver & 2.5 & $2.49 \pm 0.12$ & $2.44 \pm 0.07(33.4 \pm 0.10)$ \\
Intestine & 3.5 & $3.53 \pm 0.14$ & $3.30 \pm 0.11(30.1 \pm 0.70)$ \\
Intestine & 2.5 & $2.48 \pm 0.08$ & $2.23 \pm 0.06(34.5 \pm 0.07)$ \\
All tissues $\ddagger$ & 1.5 & $1.12 \pm 0.25$ & ND \\
\hline
\end{tabular}

ND, No amplification detected.

${ }^{*}$ A. salmonicida levels were determined by plate counts on tryptic soy agar spread plates.

$†$ Real-time PCR determination of A. salmonicida concentrations was based on the mean of duplicate samples. Concentrations were derived from a standard curve using the mean of triplicate $\mathrm{C}_{t}$ values for serial tenfold dilutions of DNA extracted from known concentrations of bacteria.

¥Individual samples of kidney, spleen, liver and intestine. 
Table 3. Quantification of $A$. salmonicida from naturally infected tissues

\begin{tabular}{|lc|}
\hline Sample & Real-time PCR $^{\star}\left[\log\right.$ c.f.u. $\left.\mathbf{g}^{-\mathbf{1}} \pm \mathrm{SD}\left(\mathrm{C}_{\mathbf{t}} \pm \mathrm{SD}\right)\right]$ \\
\hline Kidney & $3.60 \pm 0.17(29.8 \pm 0.22)$ \\
Kidney & $4.02 \pm 0.16(28.2 \pm 0.42)$ \\
Liver & $3.70 \pm 0.14(29.1 \pm 0.10)$ \\
Liver & $3.90 \pm 0.16(28.6 \pm 0.08)$ \\
Spleen & ND \\
Spleen & $2.71 \pm 0.12(33.5 \pm 0.18)$ \\
\hline
\end{tabular}

ND, No amplification detected.

${ }^{*}$ Real-time PCR determination of A. salmonicida concentrations was based on the mean of duplicate samples. Concentrations were derived from a standard curve using the mean of triplicate $C_{t}$ values for serial tenfold dilutions of DNA extracted from known concentrations of bacteria.

that bacterial concentrations were in the normal range of values.

The sensitivity obtained in this study was not greatly different from that previously reported in the literature, in which detection limits per PCR were 6 c.f.u. in pure culture (Del Cerro et al., 2002) and 30 c.f.u. (Del Cerro et al., 2002) and 200 cells $\mathrm{g}^{-1}$ (O'Brien et al., 1994) in tissue samples. In addition, a limit of detection of 2.4 cells per PCR has been reported using a slot-blot hybridization technique (Hiney et al., 1992) and a threshold limit for detection of $10^{3}$ c.f.u. $\mathrm{ml}^{-1}$ using a normal ELISA test (Adams \& Thompson, 1990).

The relative quantification of DNA using fluorogenic primers is comparable in sensitivity and dynamic range to other published methods of quantification, such as TaqMan probes (Best et al., 2005), molecular beacons (Xi et al., 2003) and DNA-binding dyes (SYBR Green) (De Medici et al., 2003). However, direct comparisons among methods for quantification are difficult as these methods are functionally different and may be affected differently by various factors.

In conclusion, the fluorogenic primer method is rapid, uses fewer toxic chemicals and is a useful tool for the sensitive and accurate detection of $A$. salmonicida in fish tissue. However, further studies should be performed in order to establish diagnostic agreement with serological methods at different stages post-infection.

\section{ACKNOWLEDGEMENTS}

This study was supported by a grant from the National Adviser Body of Continental Cultures (JACUCON). J.L.B. was supported by a fellowship from the Spanish International Cooperation Agency (AECI). We wish to express our gratitude to B. K. Gudmundsdóttir, H. Árnadóttir, J. A. Guijarro, D. Colquhoun, E. Jansson and M. J. Figueras for providing the different strains, and W. Aguirre for helpful and critical discussions. We also thank M. C. Uriel and J. Lyahyai for their technical assistance.

\section{REFERENCES}

Adams, A. \& Thompson, K. (1990). Development of an enzymelinked immunosorbent assay (ELISA) for the detection of Aeromonas salmonicida in fish tissue. J Aquat Anim Health 2, 281-288.

Altschul, S. F., Gish, W., Miller, W., Myers, E. W. \& Lipman, D. J. (1990). Basic local alignment search tool. J Mol Biol 215, 403-410.

Altschul, S. F., Madden, T. L., Schäffer, A. A., Zhang, J., Zhang, Z., Miller, W. \& Lipman, D. J. (1997). Gapped BLAST and PSI-BLAST: a new generation of protein database search programs. Nucleic Acids Res $\mathbf{2 5}$, 3389-3402.

Austin, B. \& Austin, D. A. (editors) (1999). Bacterial Fish Pathogens: Diseases of Farmed and Wild Fish, 3rd edn. Chichester: Springer - Praxis.

Best, E. L., Fox, A. J., Frost, J. A. \& Bolton, F. J. (2005). Real-time single-nucleotide polymorphism profiling using TaqMan technology for rapid recognition of Campylobacter jejuni clonal complexes. J Med Microbiol 54, 919-925.

Byers, H. K., Gudkovs, N. \& Crane, M. S. J. (2002). PCR-based assays for the fish pathogen Aeromonas salmonicida. I. Evaluation of three PCR primer sets for detection and identification. Dis Aquat Org 49, 129-138.

Del Cerro, A., Marquez, I. \& Guijarro, J. A. (2002). Simultaneous detection of Aeromonas salmonicida, Flavobacterium psychrophilum, and Yersinia ruckeri, three major fish pathogens, by multiplex PCR. Appl Environ Microbiol 68, 5177-5180.

De Medici, D., Croci, L., Delibato, E., Di Pasquale, S., Filetici, E. \& Toti, L. (2003). Evaluation of DNA extraction methods for use in combination with SYBR green I real-time PCR to detect Salmonella enterica serotype enteritidis in poultry. Appl Environ Microbiol 69, 3456-3461.

Gilroy, D. \& Smith, P. (2003). Application-dependent, laboratorybased validation of an enzyme-linked immunosorbent assay for Aeromonas salmonicida. Aquaculture 217, 23-38.

Gustafson, C. E., Thomas, C. J. \& Trust, T. J. (1992). Detection of Aeromonas salmonicida from fish by using polymerase chain reaction amplification of the virulence surface array protein gene. Appl Environ Microbiol 58, 3816-3825.

Hiney, M. \& Olivier, G. (1999). Furunculosis (Aeromonas salmonicida). In Fish Diseases and Disorders, vol. 3: Viral, Bacterial and Fungal Infections, pp. 341-425. Edited by P. T. K. Woo \& D. W. Bruno. Wallingford: CABI Publishing.

Hiney, M., Dawson, M. T., Heery, D. M., Smith, P. R., Gannon, F. \& Powell, R. (1992). DNA probe for Aeromonas salmonicida. Appl Environ Microbiol 58, 1039-1042.

Lowe, B., Avila, H. A., Bloom, F. R., Gleeson, M. \& Kusser, W. (2003). Quantitation of gene expression in neural precursors by reversetranscription polymerase chain reaction using self-quenched, fluorogenic primers. Anal Biochem 315, 95-105.

Martínez-Murcia, A. J., Saavedra, M. J., Chacón, M. R., Guarro, J., Stackebrandt, E. \& Figueras, M. J. (2005). Phenotypic, genotypic, and phylogenetic discrepancies to differentiate Aeromonas salmonicida from Aeromonas bestiarum. Int Microbiol 8, 259-269.

McCarthy, D. H. \& Roberts, R. J. (1980). Furunculosis of fish - the present state of our knowledge. In Advances in Aquatic Microbiology, pp. 293-341. Edited by M. R. Droop \& H. W. Jannasch. London: Academic Press.

Mills, S. D., Boland, A., Sory, M. P., van der Smissen, P., Kerbourch, C., Finlay, B. B. \& Cornelis, G. R. (1997). Yersinia enterocolitica induces apoptosis in macrophages by a process requiring functional type III secretion and translocation mechanisms and involving YopP, presumably acting as an effector protein. Proc Natl Acad Sci U S A 94, 12638-12643. 
Miyata, M., Inglis, V. \& Aoki, T. (1996). Rapid identification of Aeromonas salmonicida subspecies salmonicida by the polymerase chain reaction. Aquaculture 141, 13-24.

Mooney, J., Powell, E., Clabby, C. \& Powell, R. (1995). Detection of Aeromonas salmonicida in wild Atlantic salmon using a specific DNA probe test. Dis Aquat Org 21, 131-135.

Nazarenko, I., Lowe, B., Darfler, M., Ikonomi, P., Schuster, D. \& Rashtchian, A. (2002a). Multiplex quantitative PCR using selfquenched primers labeled with a single fluorophore. Nucleic Acids Res 30, e37.

Nazarenko, I., Pires, R., Lowe, B., Obaidy, M. \& Rashtchian, A. (2002b). Effect of primary and secondary structure of oligodeoxyribonucleotides on the fluorescent properties of conjugated dyes. Nucleic Acids Res 30, 2089-2195.

O’Brien, D., Mooney, J., Ryan, D., Powell, E., Hiney, M., Smith, P. R. \& Powell, R. (1994). Detection of Aeromonas salmonicida, causal agent of furunculosis in salmonid fish, from the tank effluent of hatchery-reared atlantic salmon smolts. Appl Environ Microbiol 60, 3874-3877.
Sharkey, F. H., Banat, I. M. \& Marchant, R. (2004). Detection and quantification of gene expression in environmental bacteriology. Appl Environ Microbiol 70, 3795-3806.

Sørum, H., Kvello, J. H. \& Hastein, T. (1993). Occurrence and stability of plasmids in Aeromonas salmonicida ss salmonicida isolated from salmonids with furunculosis. Dis Aquat Org 16, 199-206.

Suzuki, K., Sasaki, J., Uramoto, M., Nakase, T. \& Komagata, K. (1996). Agromyces mediolanus sp. nov., nom. rev., comb. nov., a species for "Corynebacterium mediolanum" Mamoli 1939 and for some aniline-assimilating bacteria which contain 2,4-diaminobutyric acid in the cell wall peptidoglycan. Int J Syst Bacteriol 46, 88-93.

Thompson, J. D., Higgins, D. G. \& Gibson, T. J. (1994). CLUSTAL W: improving the sensitivity of progressive multiple sequence alignment through sequence weighting, position-specific gap penalties and weight matrix choice. Nucleic Acids Res 22, 4673-4680.

Xi, C., Balberg, M., Boppart, S. A. \& Raskin, L. (2003). Use of DNA and peptide nucleic acid molecular beacons for detection and quantification of rRNA in solution and in whole cells. Appl Environ Microbiol 69, 5673-5678. 